\title{
RESPON MASYARAKAT TERHADAP RENCANA PENGEMBANGAN WISATA HALAL DI DESA KAMAL KECAMATAN KAMAL KABUPATEN BANGKALAN (Studi Kasus Masyarakat Kelurahan Kamal Kecamatan Kamal Kabupaten Bangkalan)
}

Atik Kotul Maulana1, Lailatul Qadariyah²

Program Studi Ekonomi Syariah, Universitas Trunojoyo Madura

E-mail: atikmaulana27@gmail.com ${ }^{1}$,qadariyah_82@yahoo.com²

DOI: https://doi.org/10.21107/dinar.v6i2.6117

\begin{abstract}
Abstrak
Pariwisata menjadi salah satu bidang yang dikembangkan oleb pemerintah melihat kontribusi pariwisata sebagai salah satu menyumbang devisa bagi negara Indonesia. Salah satu pengembangan pariwisata yang dilakukan adalab menjadikan pariwisata yang ramah dan nyaman dan tidak meninggalkan nilai agama yaitu pariwisata syariah. Salah satu daerah yang memiliki potensi pariwisata yang besar adalah Madura, Kabupaten Bangkalan yang terus berusaba mengembangkan wisata yang ada. Salah satu daerah yang berusaha dikembangkan untuk menjadi wisata halal adalah di desa Kamal.

Penelitian ini mempunyai tujuan untuk mengetahui respon masyarakat sekitar di desa Kamal mengenai rencana pengembangan wisata kuliner halal di desa Kamal. Jenis penelitian ini adalah penelitian kualitatif dengan metode deskriptif yang bertujuan untuk mendeskripsikan permasalahan yang akan dibahas oleh peneliti tentang respon masyarakat terhadap rencana pengembangan wisata kuliner halal di desa Kamal.

Hasil penelitian ini adalah respon masyarakat tentang rencana pengembangan wisata kuliner halal di desa Kamal mendapat respon positif, respon mereka ada yang setuju dan juga tidak setuju. Masyarakat desa Kamal sangat antusias terbadap rencana pengembangan wisata kuliner halal tersebut. Hal ini dibuktikan dengan dari semua narasumber yang diwawancarai memberikan respon setuju atau positif dan ingin ikut andil dalam pengembangan wisata kuliner halal di desa Kamal.
\end{abstract}

Kata Kunci: Respon, Masyarakat, Wisata Kuliner Halal. 


\section{Pendahuluan}

Pariwisata menjadi salah satu bidang industri yang marak dikembangkan di Indonesia. Hal ini dikarenakan kontribusi yang besar dari pariwisata sebagai salah satu penyumbang devisa bagi negara Indonesia (Muljadi \& Andri, 2016: 26). Melihat Indonesia sebagai negara kepulauan yang memiliki ribuan pulau dengan menawarkan pesona alam yang indah dan budaya yang khas dan unik menjadi potensi bagi Indonesia untuk menarik wisatawan baik lokal maupun mancanegara untuk dijadikan objek pariwisata. Salah satu daerah yang memiliki pesona alam dan budaya yang berpotensi menjadi objek pariwisata adalah Kabupaten Bangkalan Madura. Salah satu wisata yang ada di Kabupaten Bangkalan adalah wisata alam, wisata religi dan wisata kuliner.

Melihat peluang yang dimiliki oleh Kabupaten Bangkalan, dapat dikembangkan pariwisata tersebut sehingga menarik pengunjung untuk mengunjungi wisata tersebut. Beberapa tahun terakhir telah manjadi trend baru dalam dunia pariwisata yang dikembangkan menjadi pariwisata syariah. Pariwisata syariah sebagai wisata yang selain menawarkan alam dan budaya yang dimiliki juga tidak melanggar aturan agama atau sesuai dengan syariat islam. Bangkalan sebagai kota santri dan masyarakatnya kental sekali dengan nilai Islam, sangat cocok untuk mengembangkan pariwisata di Kabupaten Bangkalan menjadi pariwisata syariah. Pariwisata yang akan dikembangkan di Kabupaten Bangkalan dimulai dari pengembangan wisata kuliner halal di desa Kamal Kecamatan Kamal Kabupaten Bangkalan dengan memanfaat lahan pelabuhan timur yang sudah tidak berfungsi untuk dijadikan tempat wisata. Pengembangan wisata di desa Kamal dikonsep dengan mengembangkan wisata kuliner halal yang menawarkan kuliner khas desa Kamal khususnya dan makanan khas Kabupaten Bangkalan.

Pembangunan tempat wisata kuliner halal di Pelabuhan Kamal ini tidak akan bisa lepas dari respon masyarakat terhadap kebijakan pemerintah daerah dalam hal ini pengembangan wisata di daerah Kamal yang akan memberikan dampak sosial dan ekonomi pada masyarakat yang berada di sekitar pembangunan wisata kuliner halal tersebut. Berdasarkan kenyataan tersebut, sebelum suatu bisnis diluncurkan pada suatu kawasan tentunya diperlukan upaya penyiapan masyarakat terlebih dahulu agar mereka memiliki pengetahuan, wawasan, persepsi, respon yang positif terhadap rencana pemerintah yang ingin menerapkan wisata syariah di daerah Kamal khususnya dan Bangkalan pada umumnya sehingga mau memberikan dukungan dan ikut terlibat aktif dalam perjalanan program pembangunan wisata halal tersebut.

Berkaitan dengan rencana pengembangan wisata kuliner halal di Kamal, ini juga perlu kiranya diketahui bagaimana respon masyarakat terhadap rencana tersebut. Respon yang positif dari masyarakat tentu akan memberikan kontribusi positif terhadap implementasi rencana tersebut begitu juga sebaliknya. Karena itu penelitian ini mengkaji bagaimana respon masyakarat terhadap rencana pengembangan wisata kuliner halal di desa Kamal ini. Maka dari itu penelitian ini berjudul "Respon Masyarakat terhadap 
Rencana Pengembangan Wisata Kuliner Halal di Desa Kamal Kecamatan Kamal Kabupaten Bangkalan (Studi Kasus Masyarakat Kelurahan Kamal Kecamatan Kamal Kabupaten Bangkalan)".

\section{Landasan Teori}

\section{Pariwisata}

Pariwisata memiliki pengertian melakukan perjalanan sementara meninggalkan tempat awal menuju tempat yang lain. Dapat pula diartikan sebagai pergerakan manusia dari tempat tinggalnya menuju luar tempat tinggalnya (Fandi, 2017: 7).

Menurut Undang-Undang No. 10 Tahun 2009 tentang Kepariwisataan, pariwisata adalah berbagai macam kegiatan wisata yang didukung oleh berbagai fasilitas serta layanan yang disediakan oleh masyarakat, pengusaha, Pemerintah dan Pemerintah Daerah. Pariwisata juga dapat didefinisikan sebagai keseluruhan dari elemen-elemen terkait (wisatawan, daerah tujuan wisata, perjalanan, industri, dan lain-lain) sebagai akibat dari perjalanan wisata ke daerah tujuan wisata selama perjalanan tersebut tidak permanen (Fandi, 2017: 8).

\section{Pendekatan Pembangunan Pariwisata}

Pendekatan pembangunan pariwisata diperlukan untuk meningkatkan daya saing daerah yang memiliki potensi wisata. Ada beberapa pendekatan pembangunan pariwisata menurut Fandi (2017: 7). Pertama pendekatan pembangunan pariwisata berkelanjutan adalah pendekatan pembangunan berkelanjutan yang berusaha untuk memenuhi kebutuhan saat ini tanpa harus mengurangi kemampuan generasi yang akan datang dalam memenuhi kebutuhan. Tujuan tersebut tercapai dengan melakukan peningkatan produksi dengan memperhatikan pengelolaan yang ramah lingkungan dan menjamin adanya kesempatan yang rata dan adil bagi seluruh masyarakat. Mekanisme pembangunan berkelanjutan pada dasarnya berlangsung di suatu kawasan dalam suatu wilayah tertentu akan selalu memiliki pengaruh terhadap wilayah yang melingkupinya baik efek langsung, efek tak langsung, atau efek ikutan.

Pendekatan kedua adalah Pendekatan Pengembangan Wilayah. Pendekatan ini perlu dilakukan, karena masyarakat lokal merupakan orang-orang yang paling mengetahui mengenai kondisi sosial budaya setempat (Unggul, 2016: 64). Dengan melibatkan masyarakat sejak awal, ini lebih menjamin kesesuaianprogram pengembangan dengan aspirasi masyarakat setempat, kesesuaian dengan kapasitas yang ada, serta menjamin adanya komitmen masyarakat karena adanya rasa memiliki yang kuat. Terdapat tiga konsep utama dalam pengembangan wilayah yaitu pusat pertumbuhan (growt pole), integrasi fungsional (functional integration), pendekatan desentralisasi (decentralization approach). Sebagai industri jasa, pariwisata dimaksudkan menjadi penggerak kegiatan perekonomian wilayah sehingga perlu disediakan fasilitas-fasilitas secara lengkap untuk membantu kelancaran kegiatan (Unggul, 2016: 64-65). 


\section{Pariwisata Syariah}

Pariwisata berbasis syariah merupakan pariwisata yang produk-produk kepariwisataannya berbasis syariah atau sesuai dengan persyaratan syar'i. Dalam hal ini segala aktivitas pariwisata yang dilakukan harus menjauhi segala larangan agama seperti berasik-asik di pantai atau kolam renang dengan lawan jenis, makan atau minum yang mengandung alkohol atau babi, dan lain-lain (Unggul, 2016: 89).

Pariwisata syariah atau juga dikenal dengan pariwisata halal. Kata halal sendiri berasal dari bahasa arab yang artinya diperbolehkan atau sesuai dengan syariat atau diijinkan. Dasar agama Islam tentang pariwisata dapat dilihat dalam beberapa ayat alQur'an , sebagai berikut:

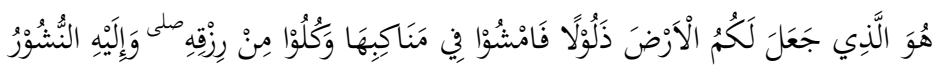

Artinya: "Dialah Yang menjadikan bumi itu mudah bagi kamu, maka berjalanlah di segala penjurunya dan makanlah sebahagian dari rezeki-Nya. Dan hanya kepada-Nyalah kamu (kembali setelah) dibangkitkan”. (Q.S al-Mulk: 15), (Departemen

Agama Republik Indonesia, 2002).

Dalam penyelenggaraan pariwisata berbasis syariah berpedoman pada Fatwa Dewan Syariah Nasional Majelis Ulama Indonesia No. 108/DSN-MUI/X/2016 tentang Pedoman Penyelenggaraan Pariwisata Berdasarkan Prinsip Syariah (Zulrizka, 2012: 18).

\section{Respon}

Respon (response) merupakan sebarang proses otot atau kelenjar yang dimunculkan oleh suatu rangsangan (J.P Chaplin terj. Kartini Kartono, 2011: 432). Respon juga dapat diartikan sebagai tindakan yang dihasilkan oleh stimulus tertentu (Syah Muhibbin, 2015: 98). Respon merupakan perilaku atau tanggapan yang terjadi pada seseorang akibat stimulus yang diterima. Dengan demikian dalam teori stimulus, respon merupakan hubungan sebab akibat (Zulrizka, 2012: 18).

Indikator respon dapat dikategorikan pada respon positif atau menerima dan respon negatif atau menolak terhadap rangsangan atau stimulus yang diberikan. Menurut Soemanto (1998) Indikator tersebut dapat diuraikan sebagai respon positif yang memiliki tindakan mendekati, menyukai, menyenangi, dan mengharapkan suatu objek dan respon negatif yang memiliki tindakan menjauhi, menghindari dan memberi objek tertentu.

Menurut Sudirman (1992:215) Indikator respon dapat dikategorikan pada beberapa kategori, yaitu: Keinginan untuk bertindak atau berpartipasi aktif, membacakan atau mendengarkan, melihat, menimbulkan atau membangkitkan perasaan dan mengamati.

\section{Sikap dan Partisipasi Masyarakat dalam Pembangunan Pariwisata}

Partisipasi masyarakat adalah suatu pemberdayaan masyarakat dengan ikut berperan dalam kegiatan penyusunan perencanaan, dan implementasi program atau proyek proyek pembangunan. Partisipasi masyarakat juga sebagai kesediaan dan kemauan masyarakat berkorban dan berkontribusi terhadap proyek pembangunan. Partisipasi harus bisa 
mengubah masyarakat dari objek menjadi subjek pembangunan oleh karena itu harus menguntungkan atau mensejahterakan masyarakat (Unggul, 2016:129). Terdapat empat bentuk partisipasi masyarakat menurut Prabowo dkk (2016:20) yaitu partisipasi buah pikir, tenaga fisik, keterampilan dan kemahiran dan modal.

\section{Metode Penelitian}

\section{Jenis Penelitian}

Penelitian ini adalah perpaduan dari penelitian kepustukaan dan penelitian lapangan, karena di awali dengan telaah bahan pustaka dan literatur. Dari segi data yang di kumpulkan, di olah, di analisis, penelitian lapangan di maksudkan untuk memperoleh data langsung ke lapangan yaitu terhadap masyarakat desa Kamal Kecamatan Kamal Kabupaten Bangkalan. Penelitian ini menggunakan metode kualitatif dengan pendekatan deskriptif yang menggambarkan dan melukiskan keadaan objek penelitian dengan memperhatikan proses interaksi komunikasi antara peneliti dengan yang diteliti (Haris, 2011: 9).

\section{Sumber Data}

Dalam penelitian ini sumber data yang digunakan dibagi menjadi dua, yaitu: Data Primer dan data sekunder. Data primer yaitu data yang didapat dari hasil wawancara dan observasi (Lexy, 2013: 157). Data primer diperoleh dari wawancara yang dilakukan kepada masyarakat sekitar daerah yang akan dijadikan tempat wisata yaitu masyarakat desa Kamal mengenai rencana pengembangan wisata kuliner halal di Kabupaten Bangkalan. Sedang data sekunder adalah data yang diperoleh dari sumber data kedua atau dari sumber data tertulis yang dibagi atas sumber buku, majalah ilmiah, sumber dan arsip, dokumen pribadi, dan dokumen resmi (Lexy, 2013: 159). Data Data sekunder yang digunakan peneliti adalah gambaran umum dan profil singkat terkait objek dan data-data lainnya yang tidak diperoleh langsung.

\section{Tekhnik Pengumpulan Data}

Dalam pengumpulan data melalui sumber data, baik itu data primer maupun sekunder, seperti yang telah diuraikan diatas, maka penelitian ini menggunakan wawancara dan dokumentasi. Wawancara merupakan salah satu dari tekhnik pengumpulan data, wawancara adalah kegiatan tatap muka yang dilakukan oleh dua orang untuk saling bertukar informasi melalui tanya jawab (Danu, 2015: 33). Secara umum, teknik pengumpulan data melalui wawancara dapat dibagi menjadi tiga yakni wawancara terstruktur, semi terstruktur dan tidak terstruktur. Berdasarkan jenis wawancara tersebut, maka peneliti menggunakan teknik wawancara semi terstruktur, karena tekhnik wawancara ini memungkinkan untuk memperoleh informasi yang lebih banyak dan mendalam dari apa yang diharapkan, dengan mewawancarai 30 responden yang dikategorikan berdasarkan jenis kelamin, pendidikan, dan pekerjaan. Pedoman wawancara yang akan digunakan berupa gambaran permasalahan yang akan ditanyakan kepada responden. 
Teknik Pengunpulan data yang kedua adalah dokumentasi, dokumentasi merupakan salah satu tekhnik pengumpulan data kualitatif dengan cara menelusuri data historis (Bungin Burhan, 2001: 152). Dokumen di klasifikasikan ke dalam beberapa jenis yakni dokumen pribadi berupa buku harian dan surat pribadi, autobiografi, serta dokumen resmi aturan lembaga, majalah, dan lain-lain. Dokumen berupa data-data dari Dinas Kebudayaan, Pariwisata, Pemuda dan Olahraga Kabupaten Bangkalan (DISBUDPARPORA) terkait.

\section{Tekhnik Analisis Data}

Analisis data kualitatif terdapat tiga tahapan yaitu: Reduksi data, penyajian data dan verifikasi data (Abdulloh \& Ahmad, 2014: 221). Reduksi data adalah teknik analisis dengan menyeleksi dan mengambil data yang dianggap penting dari data yang telah diperoleh oleh peneliti selama penelitian dari wawancara, hasil observasi, hasil studi dokumentasi menjadi satu bentuk tulisan yang sama yang akan dianalisis (Herdiansyah, 2011: 165).

Setelah melakukan reduksi data maka langkah selanjutnya yaitu model data atau penyajian data. Penyajian data merupakan cara peneliti mengolah data yang sudah diseragamkan dalam bentuk tulisan ke dalam matriks kategorisasi sesuai tema-tema yang dikelompokkan, serta memecah kategori-kategori tersebut dalam bentuk yang lebih konkret (Herdiansyah, 2011: 176). Kesimpulan merupakan tahap terakhir dalam analisis data kualitatif. Tahap terakhir yang memuat proses pengambilan keputusan yang mengarah pada jawaban dari pertanyaan peneliti yang diajukan yang mengungkap apa dan bagaimana dari penelitian tersebut (Herdiansyah, 2011: 178).

\section{Hasil dan Pembahasan}

\section{Rencana Pengembangan Wisata Kuliner Halal di Desa Kamal Kecamatan Kamal Kabupaten Bangkalan}

Rencana pengembangan wisata halal di Kamal yang terletak di Desa Kamal Kecamatan Kamal Kabupaten Bangkalan sebagai dampak dari wisata halal yang mulai memasuki daerah Kabupaten Bangkalan sudah di dengar oleh masyarakat sejak tahun 2014 silam. Kabar tersebut dikuatkan dari pendapat responden yang membenarkan kabar tersebut. Responden mengungkapkan dalam wawancaranya sebagai berikut:

Rencana pengembangan wisata kuliner halal di desa Kamal merupakan salah satu rencana pemerintah daerah Kabupaten Bangkalan melalui Badan Perencanaan Pembangunan Daerah Kabupaten Bangkalan yang tertuang dalam Rencana Strategis Badan Perencanaan Pembangunan Daerah Kabupaten Bangkalan Tahun 2013-2018, salah satu daerah dalam zona pesisir selatan yang akan menjadi kawasan pariwisata adalah Kecamatan Kwanyar, Labang, dan Kamal.

Pemerintah daerah membuat Rancangan Peraturan Daerah tentang Pariwisata Islami untuk diajukan sebagai Peraturan Daerah Kabupaten Bangkalan tentang Pariwisata, 
namun sampai saat ini masih belum disetujui dengan alasan nama yang digunakan dianggap akan memecah antar agama yang ada di Kabupaten Bangkalan mengingat masyarakat Bangkalan selain mayoritas beragama Islam juga ada yang sebagian minoritas beragama non Islam. Sehingga harus di revisi untuk memiliki Peraturan Daerah Tentang Pariwisata Islami di Kabupaten Bangkalan.

Dalam perencanaan pembangunan wisata kuliner halal dapat dikaitkan dengan Peraturan Daerah Kabupaten Bangkalan No. 7 Tahun 2017 Tentang Penyelenggaraan Kepariwisataan yang menyebutkan bahwa penyelenggaraan kepariwisataan diselenggarakan dengan prinsip menjunjung tinggi norma agama dan nilai budaya sebagai pengejawantahan dari konsep hidup dalam keseimbangan hubungan antara manusia dengan Tuhan, hubungan manusia dengan sesama manusia, dan hubungan manusia dengan lingkungan. Selain itu juga jasa makanan dan minuman yang meliputi restoran, rumah makan, jasa boga, pusat penjualan makanan dan kafe di daerah Kabupaten Bangkalan wajib menjamin kehalalan makanan dan minuman yang disajikan dan/atau mendapatkan sertifikasi halal dari Majelis Ulama Indonesia (MUI).

Dalam rencana pengembangan wisata kuliner halal di desa Kamal akan dibangun beberapa konsep yaitu: Pasar kuliner, wisata keluarga dan wisata bahari.

Pertama pasar kuliner, dalam pengembangan wisata kuliner halal di desa Kamal akan dibangun pasar kuliner yang menjual berbagai makanan dan minuman khas desa Kamal. Seperti yang disampaikan oleh Kepala Desa Kamal, Pelabuhan Timur akan dimanfaatkan menjadi pariwisata kuliner dengan akan dibangun kafe apung, wisata air, dan persewaan perahu. Namun dalam pelaksanaannya masih terkendala dengan lahan yang harus diurus karena masih terhubung dengan pihak PT. ASDP (PT. Angkutan Sungai, Danau, dan Penyeberangan). Pengembangan wisata kuliner halal di Kamal yang masih terkendala dengan lahan tersebut akan diselesaikan oleh pemerintah desa dan juga oleh pemerintah daerah dengan bekerja sama dengan pihak ASDP.

Kedua wisata keluarga, selain berkonsep pasar kuliner, desa Kamal akan mengembangkan wisata di desa Kamal dengan konsep wisata keluarga. Selain menawarkan kuliner khas Kamal yang beragam, rencananya akan disediakan pula fasilitas keluarga seperti mainan untuk anak-anak, tempat bersantai yang tidak bertentangan dengan nilai budaya masyarakat Kamal.

Ketiga wisata bahari, Selain konsep pasar kuliner dan wisata keluarga, pemerintah desa Kamal dan pemerintah daerah akan mengembangkan wisata di desa Kamal dengan konsep wisata bahari. Konsep wisata bahari yang akan dikembangkan yaitu dengan menyediakan tempat pemancingan, wisata di atas kapal, objek menyelam, dan wisata kuliner.

Selain 3 konsep di atas, pemerintah desa Kamal akan merealisasikan wisata kuliner halal dengan menggunakan tenda sepanjang jalan dari depan balai desa Kamal sampai Pelabuhan Timur. Desain wisata kuliner halal yang akan dikembangkan di desa Kamal 
Kecamatan Kamal Kabupaten Bangkalan yaitu menggunakan tenda yang sudah disiapkan oleh pemerintah desa Kamal sepanjang jalan dari depan balai desa Kamal sampai depan Pelabuhan Timur dengan masing-masing tenda menjual makanan dan minuman yang berbeda-beda.

\section{Respon Masyarakat Terhadap Rencana Pengembangan Wisata Kuliner Halal di}

\section{Desa Kamal Kecamatan Kamal Kabupaten Bangkalan}

Wisata halal merupakan segala rangkaian wisata yang menerapkan prinsip islam baik dalam pengoperasian wisata, makanan dan minuman yang djual, pelayanan, serta fasilitas yang memenuhi standar halal.

Respon yang dibahas dalam penelitian ini merupakan tanggapan atau reaksi terhadap stimulus atau rangsangan yang diberikan. Pembentukan respon berlangsung ketika seseorang menerima stimulus dari lingkungannya. Stimulus ini diperoleh dari penginderaan dunia luar atau dunia nyata, misal tentang objek-objek, peristiwa, dan hubungan-hubungan antar gejala (Zulrizka, 2012: 18). Indikator respon terdapat respon positif dan respon negatif (Soemanto, 1998: 28). Selain itu juga indikator respon yaitu membacakan atau mendengarkan, keinginan untuk bertindak dan berpartisipasi aktif, melihat, mengamati, dan menimbulkan atau membangkitkan (Sudirman, 1992: 215). Seperti yang dijelaskan dari hasil penelitian di bawah ini berdasarkan indikator respon:

\section{a. Membacakan atau mendengarkan}

Dalam hal ini responden memiliki pengetahuan tentang wisata halal dan rencana pengembangan wisata kuliner halal di desa Kamal melalui stimulus atau rangsangan membaca atau mendengar sehingga responden memberikan respon atau tanggapan seperti yang dijelaskan dalam diagram berikut:

\section{Gambar 1 \\ Membacakan atau Mendengarkan Tentang Wisata Kuliner Halal}

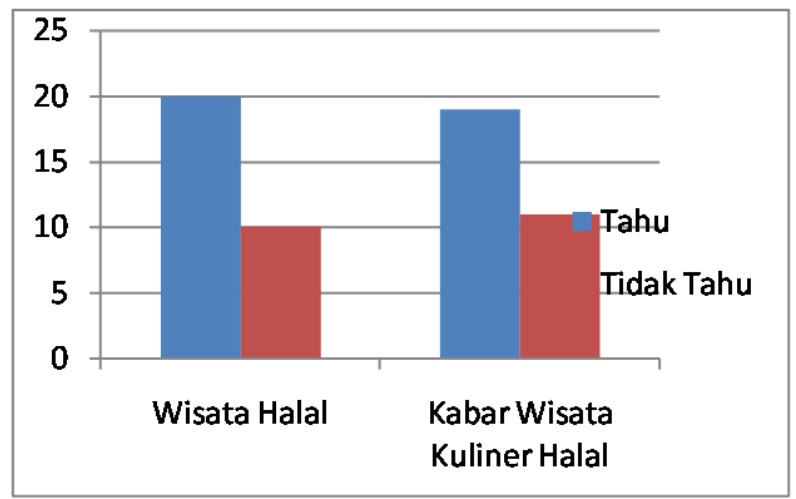

Sumber: Data Primer diolah 2019

Dalam gambar 1 dijelaskan bahwa wisata halal mampu dijabarkan oleh 20 responden atau $66,67 \%$ dengan pengertian yang berbeda-beda dari masing-masing 
responden. Sedangkan responden yang tidak dapat mengetahui tentang wisata halal sebanyak 10 responden atau 33,33\%.

Sedangkan pengetahuan tentang rencana pengembangan wisata kuliner halal dapat dilihat pada gambar 2 diketahui jumlah responden yang mengetahui rencana pengembangan wisata kuliner halal di desa Kamal berjumlah 19 responden sedangkan yang tidak tahu mengenai rencana pengembangan wisata kuliner halal di desa Kamal sebanyak 11 responden.

\section{b. Keinginan untuk bertindak atau berpartisipasi aktif}

Indikator ini menjelaskan bahwa responden akan memberikan tanggapan mengenai keinginan untuk bertindak atau berpartisipasi aktif. Dalam hal ini responden memberikan respon minat berkunjung atau tidak dan keinginan untuk ikut andil atau tidak dalam rencana pengembangan wisata kuliner halal di desa Kamal seperti yang dijelaskan dalam gambar diagram di bawah ini:

\section{Gambar 2}

\section{Minat Masyarakat untuk Berkunjung}

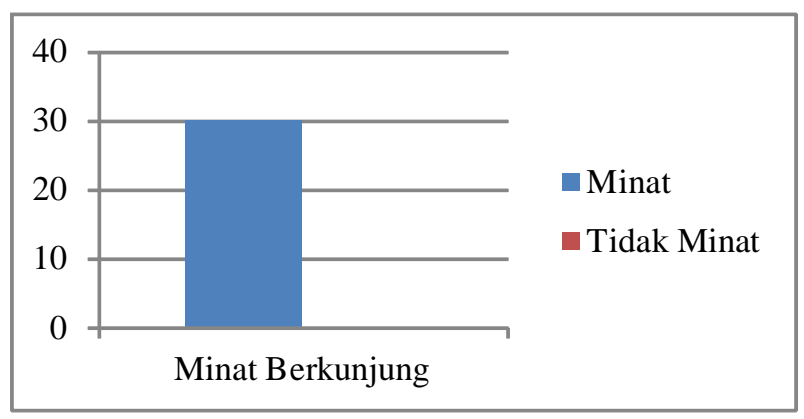

Sumber: Data Primer diolah 2019

Berdasarkan gambar 2 menggambarkan bahwa minat masyarakat untuk berkunjung apabila rencana pengembangan wisata kuliner halal terwujud. Dari hasil wawancara kepada 30 responden, didapatkan hasil bahwa seluruh responden memberikan respon bahwa mereka berminat berkunjung apabila rencana pengembangan wisata kuliner halal tersebut terlaksana.

\section{Gambar 3}

Ikut Andil dalam Pembangunan Tempat Wisata 


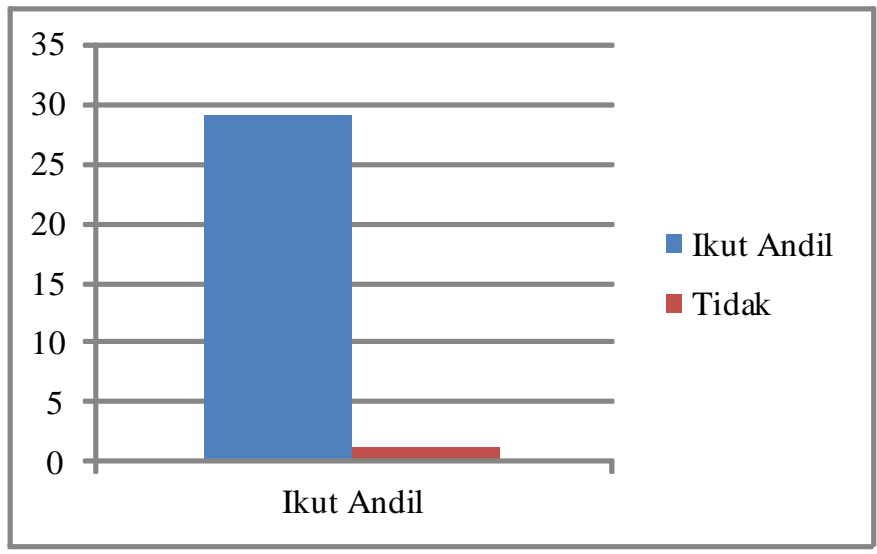

Sumber: Data Primer diolah 2019

Pada gambar 3 menjelaskan bahwa dari total 30 responden terdapat 29 orang ingin ikut andil apabila rencana pembangunan tempat wisata Kamal terlaksana sedangkan terdapat 1 responden yang ragu-ragu ingin ikut andil atau tidak dengan alasan terkendala modal dan takut tersaingi.

\section{c. Mengamati}

Indikator ini menjelaskan bahwa responden akan memberikan tanggapan atau reaksi atau respon akibat adanya stimulus berupa hasil pengamatan responden terhadap kejadian atau keadaan di lingkungannya yaitu adanya rencana pengembangan wisata kuliner halal di desa Kamal. Respon tersebut berupa pendapat responden tentang rencana pengembangan wisata kuliner halal dan pendapat tentang kelayakan desa Kamal menjadi tempat wisata kuliner halal seperti yang dijelaskan dalam gambar diagram berikut:

\section{Gambar 4}

\section{Pendapat Rencana Pengembangan Wisata di Kamal terhadap Ekonomi}

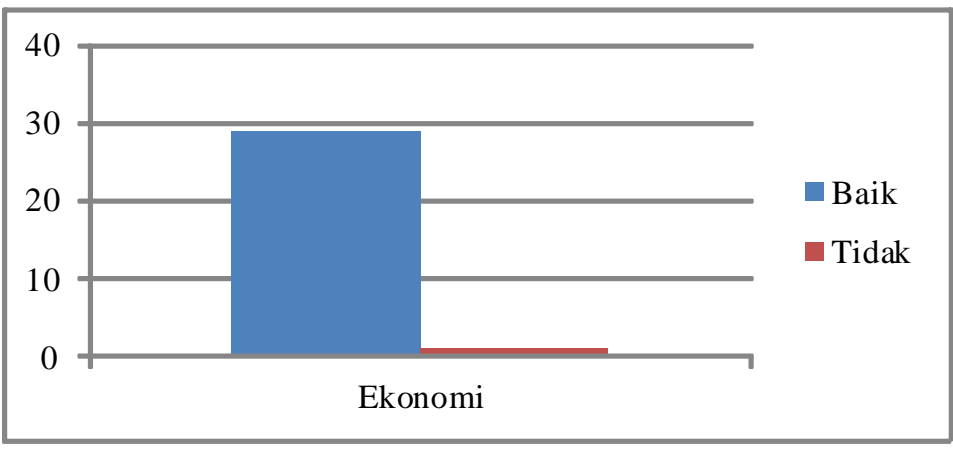

Sumber: Data Primer diolah 2019

Berdasarkan gambar 4 menjelaskan bahwa dari hasil pengamatan responden apabila desa Kamal dijadikan tempat wisata kuliner halal akan berdampak atau tidak memiliki dampak terhadap ekonomi masyarakat desa Kamal. Diketahui bahwa terdapat 29 responden memberikan pendapat bahwa dengan adanya rencana tersebut dan terlaksana akan memberikan dampak ekonomi yang baik terhadap 
masyarakat desa Kamal. Sedangkan yang berpendapat tidak memiliki dampak hanya 1 responden dari total keseluruhan responden sebanyak 30 .

\section{Gambar 5}

\section{Pendapat Kelayakan Kamal Sebagai Tempat Wisata}

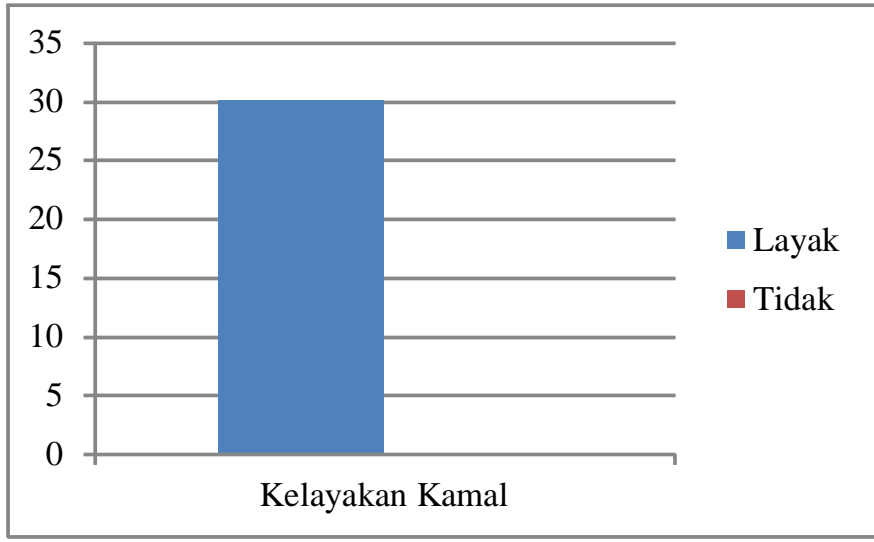

Sumber: Data Primer dikelola 2019

Pada gambar 5 menjelaskan pendapat responden tentang kelayakan desa Kamal untuk dijadikan tempat wisata kuliner halal. Dari hasil wawancara diketahui bahwa seluruh responden sepakat bahwa Kamal layak dijadikan tempat wisata yaitu sebanyak 30 responden.

\section{d. Melihat}

Dalam hal ini responden melihat peluang yang akan diambil apabila rencana pengembangan wisata kuliner halal terlaksana untuk dibangun. Dalam hal ini disebut harapan responden dari adanya rencana pengembangan wisata kuliner halal di desa Kamal Kecamatan Kamal Kabupaten Bangkalan. Dari total 30 respon, keseluruhan memiliki harapan yang hampir sama ketika melihat rencana dari adanya pengembangan wisata kuliner halal yang berlokasi di Pelabuhan Timur sampai Pelabuhan Barat. Responden berharap dengan adanya rencana pengembangan wisata kuliner halal di Kamal masyarakat Kamal dapat membuka lapangan usaha, dan memperbaiki ekonomi masyarakat. Seperti harapan yang dikemukakan oleh beberapa responden berikut:

\section{e. Menimbulkan atau membangkitkan}

Dalam hal ini juga dapat dilihat bahwa responden memberikan respon setuju atau tidak setuju terhadap rencana pengembangan wisata kuliner halal di desa Kamal Kecamatan Kamal Kabupaten Bangkalan dan tanggapan masyarakat terhadap keputusan pemerintah daerah dalam menjadikan desa Kamal sebagai tempat wisata kuliner halal. Respon diberikan ketika responden mendapat rangsangan atau stimulus tentang kondisi atau keadaan disekitar lingkungannya seperti penjelasan gambar diagram di bawah ini: 


\section{Gambar 6}

Respon Masyarakat terhadap Rencana Pengembangan Wisata Kuliner Halal di Kamal

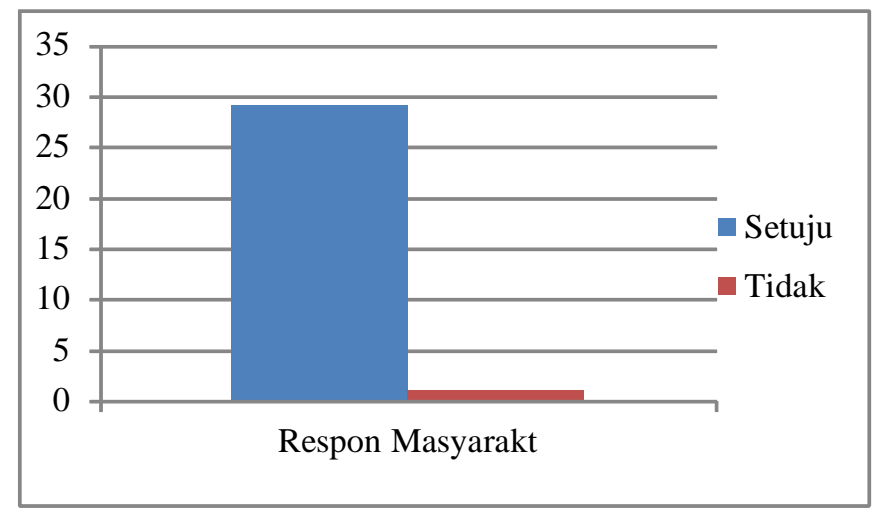

Sumber: Data Primer diolah 2019

Dari gambar 6 diketahui bahwa responden yang setuju terhadap adanya rencana pengembangan wisata kuliner halal di desa Kamal berjumlah 29 responden atau 96,67\%. Sedangkan responden yang tidak setuju dengan rencana tersebut berjumlah 1 responden atau 3,33\%.

Responden yang tidak setuju terhadap rencana pengembangan wisata dengan alasan kuputusan pemerintah daerah tidak dapat diganggu gugat walaupun dirinya sebagai rakyat kecil tidak setuju terhadap keputusan pemerintah yang dirasa akan mengancam posisinya sebagai salah satu pemilik warung di Kamal. Responden berpendapat dengan berdirinya wisata kuliner akan memberikan dampak negatif dirinya harus kehilangan warungnya dan apabila ingin tetap berjualan harus membayar sejumlah uang dan membuat responden kesulitan.

\section{Gambar 7}

\section{Tanggapan Masyarakat terhadap Keputusan Pemerintah Daerah}

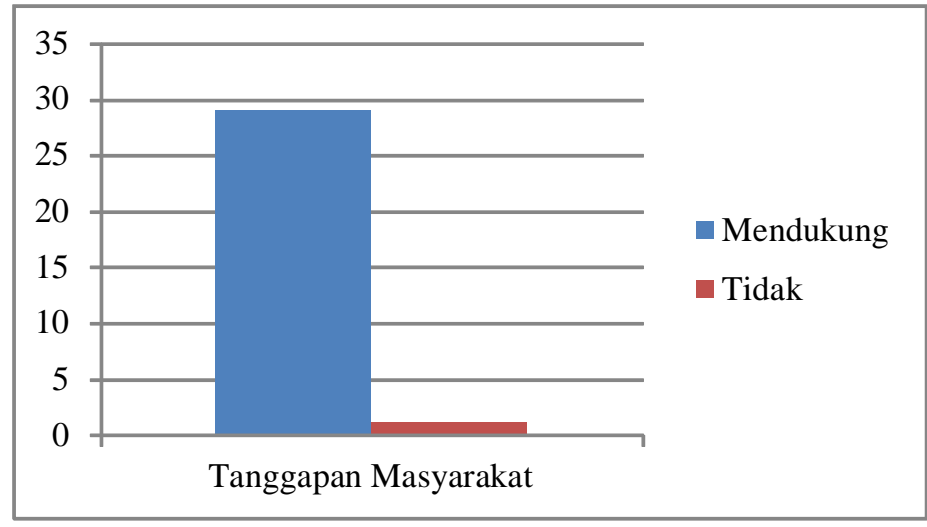


Sumber: Data Primer diolah 2019

Pada gambar 7 menggambarkan tentang respon masyarakat terhadap keputusan pemerintah daerah dalam menjadikan Kamal sebagai tempat wisata kuliner halal. Dari gambar 4.9 diketahui bahwa terdapat 29 responden atau 93,67\% memberikan dukungan terhadap keputusan pemerintah daerah dalam rencana pengembangan wisata kuliner halal di Kamal dan 1 responden atau 3,33\% yang tidak mendukung keputusan pemerintah daerah.

Beberapa indikator diatas menjelaskan bahwa masyarakat di desa Kamal Kecamatan Kamal Kabupaten Bangkalan memiliki pengetahuan, minat, tanggapan dan reaksi yang baik terkait rencana pengembangan wisata kuliner halal di desa Kamal Kecamatan Kamal Kabupaten Bangkalan. Sehingga masyarakat desa Kamal dapat digolongkan pada kategori respon positif. Dikategorikan respon positif karena kecenderungan tindakan reponden adalah mendekati, menyukai, menyenangi, dan mengharapkan suatu objek ditunjukkan dengan pengetahuan, minat, tanggapan dan reaksi masyarakat Kamal diatas 50\%.

\section{Kesimpulan}

Berdasarkan hasil penelitian yang telah dilakukan oleh peneliti di lapangan baik melalui wawancara atau dokumentasi yang didapat berkaitan dengan permasalahan dalam penelitian ini yang berjudul "Respon Masyarakat Terhadap Rencana Pengembangan Wisata Kuliner Halal di Desa Kamal Kecamatan Kamal Kabupaten Bangkalan (Studi Kasus Masyarakat Kelurahan Kamal Kecamatan Kamal Kabupaten Bangkalan)" maka dapat disimpulkan bahwa respon masyarakat desa Kamal Kecamatan Kamal Kabupaten Bangkalan berdasarkan perwakilan jumlah responden yang diwawancarai sebanyak 30 orang tergolong kedalam kategori respon positif. Masyarakat desa Kamal sangat antusias terhadap rencana pengembangan wisata kuliner halal tersebut. Hal ini dibuktikan dengan dari semua narasumber yang diwawancarai memberikan respon setuju atau positif dan ingin ikut andil dalam pengembangan wisata kuliner halal di desa Kamal. Masyarakat desa Kamal juga berharap dari adanya rencana pengembangan wisata kuliner halal cepat terlaksana dan membuat Kamal memiliki ekonomi yang lebih baik.

\section{DAFTAR PUSTAKA}

Abdulloh, S. B., \& Ahmad, B. (2014). Metode Penelitian Ekonomi Islam Muamalah. Bandung: CV Pustaka Setia.

Bungin Burhan. (2001). Metodologi Penelitian Sosial: Format-format Kuantitatif dan Kualitatif. Surabaya: Airlangga University Pers.

Danu, A. E. (2015). Memahami Metode Penelitian Kualitatif Teori dan Praktik. Yogyakarta: Calpulis.

Departemen Agama Republik Indonesia. (2002). Al-Qur'an dan Terjemahannya. Jakarta: CV 
Pustaka Harapan.

Fandi, E. S. R. (2017). Psikologi Pariwisata Madura. Malang: AE Publishing.

Haris, H. (2011). Metodologi Penelitian Kualitatif untuk Ilmu-Ilmu Sosial. Jakarta: Salemba Humanika.

Herdiansyah Haris. (2011). Metodologi Penelitian Kualitatif untuk Ilmu-Ilmu Sosial. Jakarta: Salemba Humanika.

J.P Chaplin terj. Kartini Kartono. (2011). Kamus Lengkap Psikologi. Jakarta: PT RajaGrafindo Persada.

Lexy, M. J. (2013). Metodologi Penelitian Kualitatif. Bandung: PT Remaja Rosdakarya.

Muljadi, \& Andri, A. W. (2016). Kepariwisataan dan Perjalanan (2nd ed.). Jakarta: PT RajaGrafindo Persada.

Prabowo, S. E., Hamid, D., \& Prasetya, A. (2016). Analisis Partisipasi Masyarakat Dalam Pengembangan Desa Wisata (Studi Pada Desa Pujonkidul Kecamatan Pujon Kabupaten Malang). Jurnal Administrasi Bisnis, 33(2), 18-24.

Soemanto. (1998). Psikologi Pendidikan: Landasan Kerja Pemimpin Pendidikan. Jakarta: Rineka Cipta.

Sudirman, A. (1992). Interaksi dan Motivasi Belajar Mengajar. Jakarta: Rajawali Pers.

Syah Muhibbin. (2015). Psikologi Belajar. Jakarta: Rajawali Pers.

Unggul, P. (2016). Pariwisata Syariah Prospek dan Perkembangan. Yogyakarta: UPP STIM YKPN.

Zulrizka Iskandar. (2012). Psikologi Lingkungan: Teori dan Konsep. Bandung: PT Refika Aditama. 